\title{
High accuracy Land Use Land Cover (LULC) maps for detecting agricultural drought effects in rainfed agro-ecosystems in central Mexico
}

\author{
Andres SIERRA-SOLER ${ }^{1)}$ ABCDEF, Jan ADAMOWSKI ${ }^{\text {1) ABCDEF, }}$ \\ Zhiming QI ${ }^{1) \text { DEF }}$, Hossein SAADAT ${ }^{1) \text { DEF }}$, Santosh PINGALE ${ }^{2) \text { DEF }}$
}

\footnotetext{
1) McGill University, Faculty of Agricultural and Environmental Sciences, Department of Bioresource Engineering, Quebec, Canada, H9X 3V9; e-mail: jan.adamowski@mcgill.ca

${ }^{2)}$ Arba Minch University, Department of Water Resource and Irrigation Engineering, Arba Minch, P.O. Box 21, Ethiopia; e-mail: pingalesm@gmail.com
}

For citation: Sierra-Soler A., Adamowski J., Qi Z., Saadat H., Pingale S. 2015. High accuracy Land Use Land Cover (LULC) maps for detecting agricultural drought effects in rainfed agro-ecosystems in central Mexico. Journal of Water and Land Development. No. 26 p. 19-35.

\begin{abstract}
Satellite remote sensing provides a synoptic view of the land and a spatial context for measuring drought impacts, which have proved to be a valuable source of spatially continuous data with improved information for monitoring vegetation dynamics. Many studies have focused on detecting drought effects over large areas, given the wide availability of low-resolution images. In this study, however, the objective was to focus on a smaller area $\left(1085 \mathrm{~km}^{2}\right)$ using Landsat ETM+ images (multispectral resolution of $30 \mathrm{~m}$ and $15 \mathrm{~m}$ panchromatic), and to process very accurate Land Use Land Cover (LULC) classification to determine with great precision the effects of drought in specific classes. The study area was the Tortugas-Tepezata sub watershed (Moctezuma River), located in the state of Hidalgo in central Mexico. The LULC classification was processed using a new method based on available ancillary information plus analysis of three single date satellite images. The newly developed LULC methodology developed produced overall accuracies ranging from $87.88 \%$ to $92.42 \%$. Spectral indices for vegetation and soil/vegetation moisture were used to detect anomalies in vegetation development caused by drought; furthermore, the area of water bodies was measured and compared to detect changes in water availability for irrigated crops. The proposed methodology has the potential to be used as a tool to identify, in detail, the effects of drought in rainfed agricultural lands in developing regions, and it can also be used as a mechanism to prevent and provide relief in the event of droughts.
\end{abstract}

Key words: drought, LULC maps, remote sensing, spectral indices

\section{INTRODUCTION}

Droughts occur in all climatic zones and are mostly related to the reduction of precipitation received over an extended period, such as a season or a year [MAHMOOD et al. 2015; SAADAT et al. 2011; SIERRA-SOLER et al. 2015]. The impacts of a drought increase slowly and often accumulate over many months, and may linger years after the end of the drought [BELAYNEH et al. 2014; SAADAT et al. 2014]. Unlike other natural hazards, the impacts of droughts are often spread over large geographical areas. Droughts rank first among all natural hazards when measured in terms of the number of people affected 
[HewitT 1997; Mishra, Singh 2010; OBASI 1994; WILHITE et al. 2007], which emphasizes the importance of investigating how this natural phenomenon disturbs ecological and socio-economic systems [DANESHMAND et al. 2014; NAMDAR et al. 2014; NIAZI et al. 2014].

Droughts affect virtually all regions; however, they do so in such a variety of ways that each system often has its own concept of drought, and its own criteria for gauging the severity of drought. Defining drought is therefore difficult [REDMOND 2002], since it is relative to the system of interest. Differences in hydro-meteorological variables and socio-economic factors as well as the stochastic nature of water demands in different regions around the world have become an obstacle to having a universal definition of drought [MiSHRA, SiNGH 2010].

This study focused on developing an original methodology for investigating agricultural drought in semiarid developing regions where drought poses a significant threat to rainfed smallholder farmers. The methodology was tested in central Mexico but has the potential to be used in other regions with similar conditions. Rainfed agricultural production in these areas is focused mainly on producing self-sufficiency crops for the poorest sectors in society that depend on this economic activity. Agricultural drought occurs when there is not enough available plant soil moisture in the root zone [JOHAN 2003]. Agricultural drought is generally characterized by two key factors: the estimated water demand and expected water supply. The formulation of these key factors for a region largely depends on the agro-climatic conditions [YUREKLI, KURUNC 2006]. The capacity of soils to retain and release water depends on factors such as soil texture, depth, structure, organic matter content, and biological activity [BOT, BENITES 2005].

Remotely sensed approaches have been used to detect agricultural drought, and are often associated with image reflectance using spectral indices to indicate vegetation condition such as the normalized difference vegetation index $N D V I$, and soil/vegetation wetness such as the normalized difference wetness index $N D W I$ and the tasseled cap wetness $T C W$, described below.

The normalized difference vegetation index NDVI is a spectral index that has been shown to be highly correlated with parameters associated with plant health and productivity, and has been widely used for drought detection [BARBOSA et al. 2006; KogAn 1995a; LeNNeY 1995; Peters et al. 2002; RAHIMZADEH-BAJGIRAN et al. 2012]. The NDVI has been used successfully to identify stressed and damaged crops and pastures but interpretive problems arise when results are extrapolated over nonhomogeneous areas. NDVI has two components: ecology and weather. The need for multi temporal NDVI analysis for detecting drought is because in any single NDVI image in a given growing season, barren fields may be indistinguishable from temporarily fallow healthy fields, and immature crops with low-density cover could be confused with poor crops [LENNEY et al. 1996]. Therefore, when NDVI has been used for the analysis of weather impact on vegetation, the weather component must be separated from the ecosystem component [RAHIMZADEH BAJGIRAN et al. 2008]. It has also been found that NDVI correlates with net primary production, biomass, vegetation fraction, and yield [GOWARD et al. 1985; LENNEY et al. 1996; MASELLI et al. 1992; QUARMBY et al. 1995; RASMUSSEN 1992; UNGANAI, KOGAN 1998].

The NDWI proposed by GAO [1996] can be obtained using the near infrared NIR and shortwave infrared SWIR channels. Gao found that NDWI is a measure of liquid water molecules in vegetation canopies that interact with the incoming solar radiation, and is less sensitive to atmospheric scattering effects than NDVI. GU et al. [2007; 2008] evaluated the relationship between $N D V I$ and $N D W I$ using MODIS 500-m satellite imagery in Oklahoma and Kansas, USA. They found good correlation between the two indices; they also found that NDWI was more sensitive to drought than NDVI. RHEE et al. [2010] sought to identify a drought index that had the possibility to be used for agricultural drought monitoring in arid/semiarid regions, as well as humid/sub-humid regions, while also using MODIS data. They found that NDWI has a better response in arid/semiarid regions than in humid regions when detecting drought because of good correlations with other precipitation and temperature indices. It is convenient to detect drought at larger scales using coarse resolution imagery such as MODIS; however, this approach cannot provide detailed land cover response to precipitation anomalies.

In semi-arid developing regions, medium resolution remotely sensed data has been used to assess the impacts of drought. VANDERPOST et al. [2011] used Landsat imagery to assess the long-time condition of rangeland in semiarid areas of Botswana. By calculating vegetation indices, they found significant degradation in vegetation corresponding to the droughts between 1984 and 2000. The technique used was limited by the many gaps in the long-time coverage, and hence there was a lack of continuity in terms of change.

The tasseled cap transformation TCT has been widely used for vegetation mapping and monitoring land cover change [FADHIL 2011; JIN, SADER 2005; OETTER et al. 2001]. The TCT of Landsat thematic mapper consists of six multispectral features, all of which could be potentially differentiated in terms of stability and change in a multitemporal data set [JIN, SADER 2005]. The first three features have been labeled brightness, greenness, and wetness (band 1, 2, and 3 , respectively). The third feature, wetness, has been shown to be sensitive to soil plant moisture [JIN, SADER 2005]. Tasseled cap wetness $T C W$ contrasts the sum of the visible and the near-infrared bands with the sum of the shortwave bands [JIN, SADER 2005]. 
The $N D W I$ and $T C W$ have both been used in studies to detect drought or disturbance in ecosystems. JIN and SADER [2005] used a time series of both NDWI and $T C W$ derived from Landsat to compare forest disturbances in Maine, USA. They found high correlations $(>0.95)$ between the two indices. FADHIL [2011] used $N D W I$ and $T C W$ to detect drought effects on vegetation in the Iraqi Kurdistan region. He derived both spectral indices from two Landsat images from consecutive years to calculate five vegetation and soil/vegetation moisture indices and performed change detection. This study did not include a classification of the vegetation, so it is unclear how the different kinds of vegetation were affected by the drought.

The response to drought effects is differentiated by the vegetation cover, but none of the abovementioned spectral indices has the potential to classify on their own crops from other classes. The knowledge of Land Use Land Cover LULC plays an important role in identifying areas where the effects of drought can cause damage in ecosystems and in agricultural lands. The identification of rainfed crops and dynamics over different precipitation conditions has not been thoroughly and explicitly explored in the past. In this study, the delineation accuracy of agricultural lands and specifically where dry-land farming is practiced was of great importance. There are many approaches that have been used to associate image reflection data with vegetation characteristics. Over the last decades, various studies have shown the efficacy of satellite imagery in characterizing vegetation cover [DE ASIS, OMASA 2007; FOCARDI et al. 2008; JOSHI et al. 2006] forests [LABRECQUE et al. 2006; SIVANPILLAI et al. 2007] and crops [COHEN, SHOSHANY 2002; WARDLOW et al. 2007]. Additionally, several authors have used LULC maps in satellite based agricultural drought monitoring [DIOUF, LAMBIN 2001; RHEE et al. 2010; WILHELMI, WiLHITE 2002].

In this study, the objective was to develop an original methodology to acquire very accurate Land Use Land Cover LULC maps to report in depth the effects of drought in rainfed agricultural lands in Central Mexico. Given the advent of climate change and increasingly severe extreme events such as droughts in many different parts of the world [ADAMOWSKI et al. 2009; 2010; 2012a, b; ADAMOWSKI, РROKOPH 2013; ARAGHI et al. 2015; CAMPISI et al. 2012; HAIDARY et al. 2013; NALLEY et al. 2012; 2013; PINGALE et al. 2013; TIWARI, ADAMOWSKI 2013], these types of maps will be useful in helping to manage water resources more sustainably [BUTLER, ADAMOWSKI 2015; HALBE et al. 2013; INAM et al. 2015; KolinJIVADI et al. 2014a, b; MEDEMA et al. 2014a; b; STRAITH et al. 2014]. Four medium resolution Landsat ETM+ images were used, corresponding to early and late summer. According to local farmers, during the early summer in a normal year vegetation is usually in development and then progresses to maturity through the end of the same season. This season in central Mexico corresponds to June and August, and the years analyzed in this study were 2000 and 2005 . These specific years were chosen based on a previous study for the same study area by SIERRA-SOLER et al. [2015] that analyzed Standardized Precipitation Index SPI trends for the period 1975-2013. In this study, the year 2000 consistently showed positive values of $S P I$ (normally wet conditions) and 2005 continually showed negative SPI values (corresponding to abnormally dry conditions). After the classification of the four images was completed, spectral indices indicating vegetation condition $N D V I$ and soil/vegetation moisture (NDWI and $T C W$ ) were calculated. The classification helped to interpret how different vegetative covers were affected by the low precipitation registered in 2005. This methodology has the potential to be used as a tool to identify, in detail, the effects of drought in rainfed agricultural lands in developing regions, and it can also be used as a mechanism to prevent and provide relief in the event of droughts.

\section{STUDY AREA}

The Tortugas-Tepezata sub watershed (Fig. 1) is one of the sub-watersheds of the Moctezuma River, and is located in the state of Hidalgo in central Mexico. The Moctezuma River is inside the Panuco Hydrological Region that flows from the Valley of Mexico into the Gulf of Mexico. The Panuco River Hydrologic Region covers most of the state of Hidalgo, with runoff coefficients in the range of 20 to $30 \%$ [CONANP 2003]. This hydrologic region has been divided into two: High Panuco and Lower Panuco. The study area is in the first, the High Panuco.

The interest of studying this semiarid area of central Mexico is due to the importance of rainfed agriculture in the region. Even though there are other economic activities such as tourism, the majority of the rural towns in the area depend directly or indirectly on

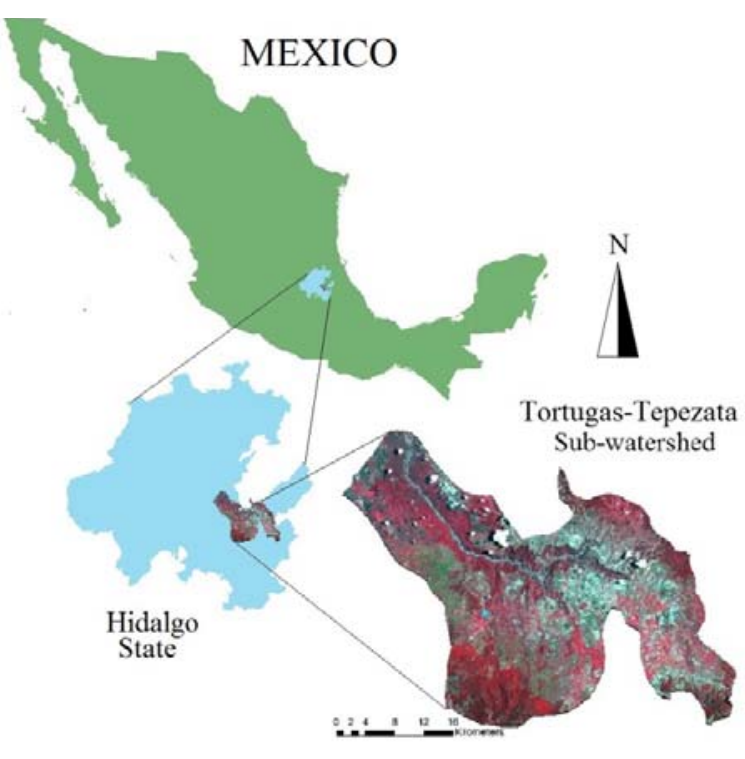

Fig. 1. Location of the study area; source: own elaboration 
local agriculture for food security. Furthermore, social exclusion, poverty, illiteracy, and access to services make this particular region vulnerable in the event of droughts.

The Metztitlán basin, along with Tortugas Tepezata basin, originates in the Amajac River. The main feature of the sub watershed is the river canyon that flows $100 \mathrm{~km}$. There are three major sections: the first entry to South Canyon with the Rio Grande Tulancingo, the second at the junction with the San Sebastian River and Venados River, and the third starts at District 08 Metztitlán (the Metztitlán River), north of the sub-basin. This river runs SE to NW, and the $\mathrm{N}$ flows into the Metztitlán Lagoon north of the Tortugas-Tepezata watershed. In the geological past, the river ran without forming the lagoon, but during the Holocene the Cerro El Tajo suffered a massive collapse forming the reservoir [CONANP 2003]. The climate is generally warm, dry, and semidry in different parts, which is determined by the rain shadow effect the Sierra Madre Oriental has on this region. The mean annual temperature is around $20-24^{\circ} \mathrm{C}$. In the rainy season, during the summer, trade winds release their moisture on the windward side and the elevated parts of the mountain range, where forests are pine and oak, among other cold temperate vegetation [CONANP 2003].

In Mexico, drought monitoring at the national scale is performed via the North America Drought Monitor (NADM), which is a cooperative effort between drought experts in the United States, Mexico, and Canada. The data produced by NADM focuses only on three data driven indexes: the SPI, the PDSI, and the Percent of Average Precipitation. Other studies in Mexico have reported qualitative drought impacts, documenting smallholder rainfed maize production and climatic risk [EAKIN 2000], climate change impacts on food security [APPENDINI, LIVERMAN 1994], estimates of the effects of El Niño Southern Oscilation (ENSO) on crop yield, and vulnerability and adaptation to drought [LIVERMAN 1990]. However, very little has been done in the region using remotely sensed data in combination with meteorological analysis to estimate the effects of drought on rainfed agricultural production, making this study both original and significant.

\section{MATERIALS AND METHODS}

\section{MATERIALS}

1. Four Landsat ETM+ Satellite Images: corresponding to the available images for the initial and final stages of summer (June 25 and August 28, 2000 and June 07 and August 10, 2005). These images were chosen because they were all the images available that were clear from clouds for the desired period. Each scene selected included the entire surface of the study area. The scenes were carefully selected for different periods of time according to the different seasons that represented different stages of vegetation development. This was done with the purpose of comparing rainfed crop conditions in seasons with normal versus dry precipitation conditions.

2. Two digital ancillary layers were also collected to assist in the interpretation and classification of the remotely sensed data. These were a 1:25000 topographic map, and a 1:50 000 scale climatic zone map. These maps were used to follow SAADAT et al.'s [2011] methodology for the development of the LULC maps.

3. Ground Truth Data: 132 samples were collected via fieldwork across all the study areas where roads permitted access. Each sample comprised cataloguing different land use and land cover classes that were used to create ground truth maps for assessing the accuracy of the supervised classification performed by the remote sensing software (explained below). The visits were performed accompanied by a hired native guide and driver familiar with the area, and with a good understanding of the local agricultural practices. Farmers, residents, and local authorities were engaged in conversation with the intent of investigating agricultural practices, past natural disasters (such as droughts, fires and floods) and land use changes in the past $10-15$ years.

4. ERDAS Imagine (version 8.7) and Arc Info (version 9) software were used for image classification, drought indices, processing, and data analyses.

\section{LULC CLASSIFICATION}

\section{General description}

Classification of Landsat ETM+ images following SAADAT et al.'s [2010] methodology proceeded in five general steps: (i) preprocessing of the images, (ii) random extraction of a training sampling location: an unsupervised classification and two digital ancillary layers served in identifying potential LULC areas to aid in identifying sampling points, (iii) supervised classification of the image into LULC classes, (iv) enhancement of the LU classification via image segmentation and zonal statistics, and (v) enhancement of the LC classification via NDVI. Each step is described below in detail.

\section{Preprocessing images}

The Landsat ETM+ satellite products have 8 individual bands, each representing different portions of the electromagnetic spectrum. The four Landsat ETM+ were subject to preprocessing, which consisted of several steps (Fig. 2). Bands $1-5$ and 7 range in the visible spectrum blue, green, red, near-infrared NIR, and mid infrared $M I R$, with $30 \mathrm{~m}$ of spatial resolution, a panchromatic band with $15 \mathrm{~m}$ band 8 , and a thermal band with $60 \mathrm{~m}$ resolution band 6 . Given the low resolution of the thermal band, 6.1 and 6.2 were not used. Bands 1-5 were combined into a multilayer im- 


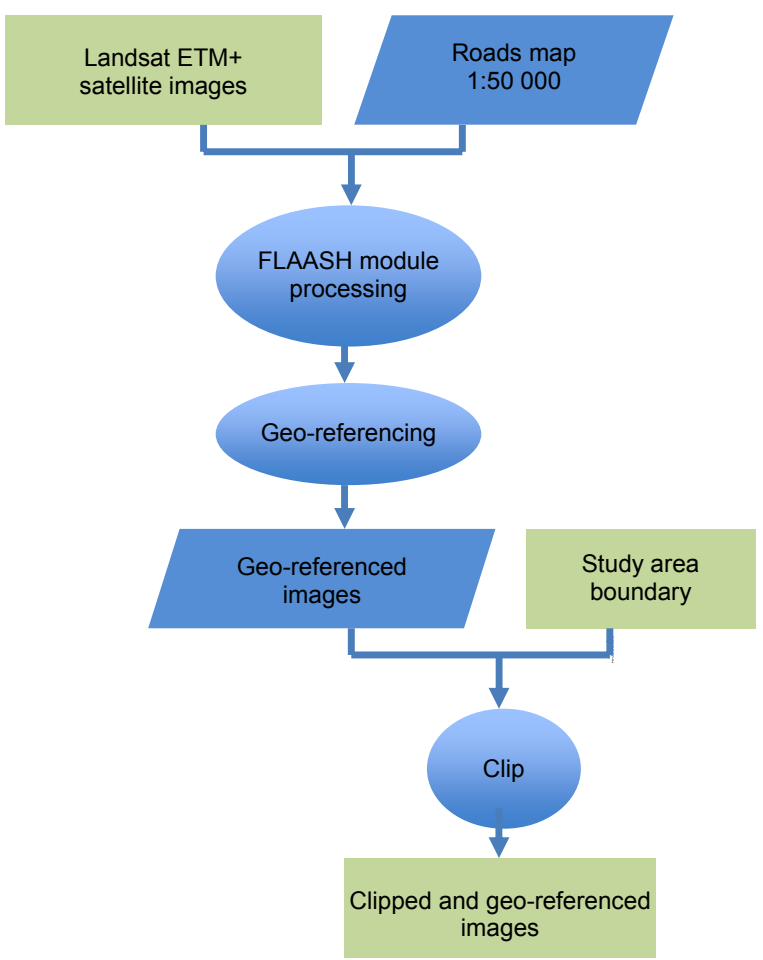

Fig. 2. Image preprocessing; source: own elaboration

age and the study area was clipped. Pan-sharpening (or image fusion) was performed with the objective of providing better image resolution. This was performed by fusing the $30 \mathrm{~m}$ resolution multilayer with the $15 \mathrm{~m}$ resolution panchromatic image. The PCA method was used because a major goal of this technique is to reduce data file size, while still retaining the spectral information of the six ETM+ bands [SAADAT et al. 2011].

Atmospheric effects such as the amount of water vapor, distribution of aerosols, and scene visibility affect the raw imagery. Such effects were eliminated so that images taken in different times could be compared accurately.

The Fast Line-of-sight Atmospheric Analysis of Spectral Hypercubes (FLAASH) atmospheric correction module in ENVI software was used for atmospheric correction to retrieve spectral reflectance data from the multispectral Landsat ETM+ images. Images were subjected to geo-referencing and image-to-image registration was performed. This process was verified by importing the tracks recorded from the GPS that were obtained during fieldwork as ground control points. After preprocessing of all images was completed, the study area was clipped from each scene.

\section{Extraction of a training sampling location}

Training samples were chosen to encompass a full variety of potential LULC classes such as forest, irrigated agriculture, pastureland, rainfed agriculture, shrubs, and water bodies across the study area. This process (Fig. 3) was performed by processing an unsupervised classification with 20 different classes with $95 \%$ of convergence threshold and maximum iterations of 10. This map was used as support to identify sampling locations across the study area, which was used to support the accuracy of the supervised classification. The total number of training sampling locations used for the study was 150 ; however, due to the inaccessibility of some of these areas, only 132 training sampling locations were recorded during the performed fieldwork during the months of January-March 2013.

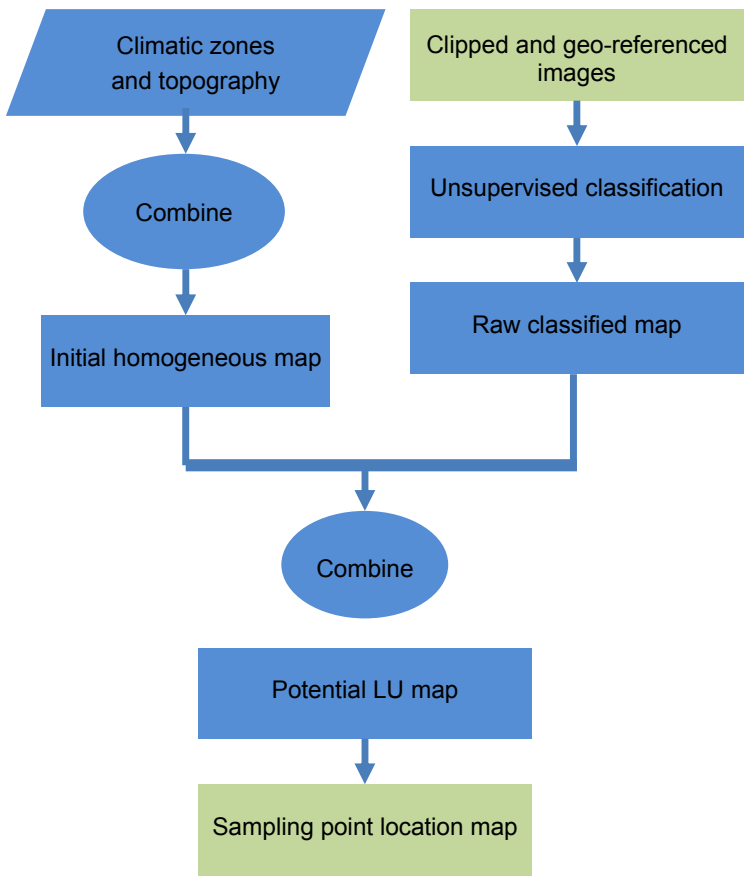

Fig. 3. Extraction of sampling point location map; source: own elaboration

\section{Supervised classification of the images into LULC classes}

Six classes were identified to describe the rural landscape in central Mexico for the supervised classification (Fig. 4). Land use land cover (LULC) was classified as follows: rainfed agriculture (RA), irrigated agriculture (IA), forest (F), shrubland (Sh), pastureland (P), and water bodies (W). SAADAT et al. [2011] further classified pasturelands and forests using differences in densities; however, for the purposes of this study, the process was not needed since the focus was to understand the response of rainfed agriculture to drought. To increase the accuracy of these maps, a $\chi^{2}$ threshold at $90 \%$ confidence level was applied to the results. In this process, the identification pixels had a $10 \%$ chance of being misclassified. These pixels were put into class " 0 " and defined as "unknown" areas. These unknown areas were reviewed observing their spectral signatures and resampling adjacent areas. Again, a supervised classification was performed with the samples plus the spectral signature sampling points until only a small pixel group (about $1 \%$ of the total area) was left unclassified. 


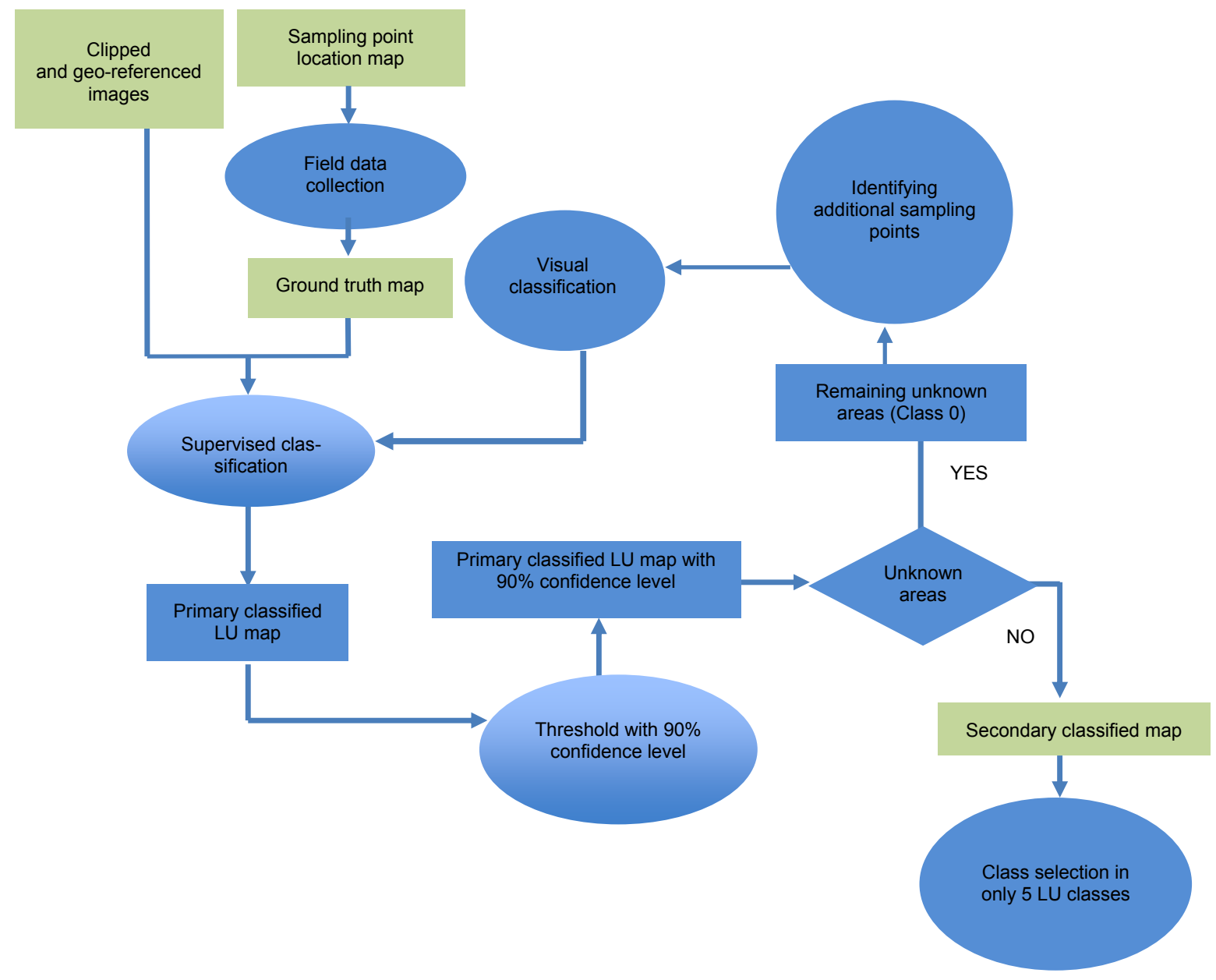

Fig. 4. Supervised classification; source: own elaboration

\section{Image segmentation and zonal statistics}

In an effort to further increase classification accuracy, an image segmentation algorithm was applied to the Landsat ETM+ images (Fig. 5) using the Bonnie Ruefenacht algorithm [RUEFENACHT et al. 2002]. Image segmentation is a process used as a way of partitioning raster images into segments based on pixel values and locations. Pixels that are spatially connected and have similar values are grouped in a single segment to isolate objects of varying size, shape, and homogeneity. This algorithm merges groups of pixels into polygon objects (raster to vector format) but it is unable to classify them [SAADAT et al. 2011], thus the need for combining the images with zonal statistical analysis.

The zonal statistics present a distribution of each LULC within each segmented polygon. The reason for image segmentation is to use the resultant polygon vector map in combination with the supervised classification raster map and zonal statistics to generate a new classified polygon map, the idea being to eliminate mixed pixels. It was found that for the six LU classes, the majority distribution was always more than $90 \%$ within any one segmented polygon. Thus, each segmented polygon was fully classified to the
$90 \%$ majority, creating one layer for each of the six LU classes.

\section{Assessing the accuracy of remotely sensed data}

To evaluate the accuracy of the LULC maps that were processed, reference sampling locations were chosen to encompass the complete variety of the classes throughout the study area. Also, climate and topographic maps were taken into account to perform sampling. In total, 132 sites were extracted based on the stratified random sampling procedure. Each sample comprised cataloguing different land use and land cover classes that were used to create ground truth maps for assessing the accuracy of the supervised classification performed by the remote sensing software. The field work was performed accompanied by a hired local guide and driver who had significant knowledge of the area and of the local agricultural practices. Farmers, residents, and local authorities were interviewed with the intent of investigating agricultural practices, past natural disasters (such as droughts, fires and floods), and land use changes in the past $10-15$ years. This process was recorded by importing the tracks and control points recorded from the GPS and complemented with photographic evidence. 


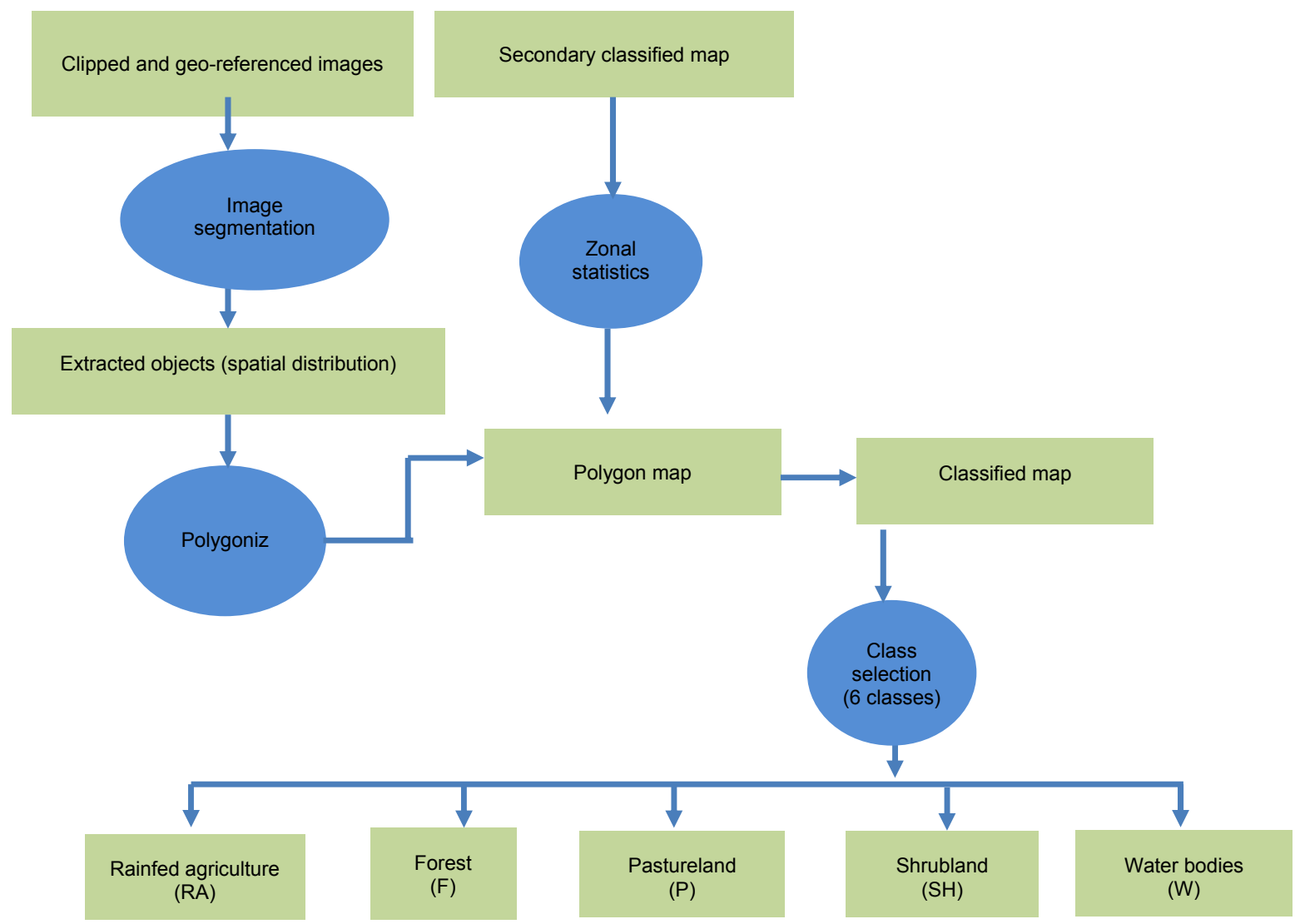

Fig. 5. Image segmentation and zonal statistics; source: own elaboration

\section{Spectral analysis for detecting drought effects on vegetation}

A drought index is a prime variable for assessing the effect of a drought and defining different drought parameters, which include intensity, duration, severity, and spatial extent [MISHRA, SINGH 2010]. It should be noted that a drought variable should be able to quantify the drought for different time scales for which a long time series is essential. The most commonly used time scale for drought analysis is a year, followed by a month [MISHRA, SINGH 2010]. The yearly time scale can be used to abstract information on the regional behavior of droughts, while the monthly time scale is more appropriate for monitoring the effects of drought in situations related to agriculture, water supply, and groundwater abstractions [PANU, SHARMA 2002]. A time series of drought indices provides a framework for evaluating drought parameters of interest [MISHRA, SINGH 2010]. To encompass a drought's effects on the different classes of vegetation cover, two vegetation conditions and vegetation/soil moistures were chosen.

\section{Normalized difference vegetation index $N D V I$}

NDVI was designed on the premise that healthy vegetation has a low reflectance in the visible portion of the electromagnetic spectrum due to the absorption by chlorophyll and other pigments and high reflec- tance in the Near Infrared NIR because of the internal reflectance by the mesophyll spongy tissue of a green leaf. $N D V I$ is calculated as the ratio of the red $R E D$ and the Near Infrared NIR bands of a sensor system, and is represented by the following equation [KOGAN 1995a]:

$$
N D V I=\frac{N I R-R E D}{N I R+R E D}
$$

$N D V I$ values range from -1 to +1 . Because of high reflectance in the NIR portion of the electromagnetic spectrum, healthy vegetation is represented by high $N D V I$ values between 0.05 and 1. Higher $N D V I$ indicates a greater level of photosynthetic activity. Conversely, non-vegetated surfaces such as water bodies yield negative values of NDVI. Bare soil areas have $N D V I$ values close to 0 due to higher reflectance in both the visible and the NIR portions of the electromagnetic spectrum [RAHIMZADEH BAJGIRAN et al. 2008].

\section{The normalized difference water index $N D W I$}

The normalized difference water index $N D W I$ is a more recent satellite-derived index from the NIR and short wave infrared SWIR channels that reflect changes in both the water content and spongy mesophyll in vegetation canopies. NDWI is calculated as follows [GAO 1996]: 


$$
N D V I=\frac{N I R-M i d I R}{N I R+M i d I R}
$$

where $N I R$ is the Near Infrared band and MidIR is the Mid Infrared Band.

Because NDWI is influenced by both desiccation and wilting of vegetative canopy, it may be a more sensitive indicator than NDVI for drought monitoring [MISHRA, SINGH 2010]. NDVI and NDWI sense similar depths through vegetation canopies. However, $N D W I$ is less sensitive to atmospheric effects than NDVI. NDWI does not completely remove the background soil reflectance effects, similar to NDVI because the information about vegetation canopies contained in the $1.24 \mu \mathrm{m}$ channel is very different from that contained in the red channel [GAO 1996]. For this reason, $N D W I$ should be considered complementary but not a substitute for $N D V I$.

$N D W I$ was calculated for the 18 Landsat ETM+ images. In the same way as previously done for $N D V I$, the $N D W I$ output layers were divided by the LULC classes and in this way each class could be analyzed separately, and a NDWI time series per class was plotted with the purpose of discerning the different $N D W I$ values per class in different stages of the growing seasons in the two dry and normal years.

\section{Tasseled cap transformation wetness $T C W$}

Numerous methods have been developed for transforming available information from multispectral sensors to derive features to interpret characteristics of the land surface. Such methods include the three indices based on ratios and differences of bands. The Tasseled Cap Transformation of Landsat Multispectral Scanner and Thematic mapper [CRIST, CICONE 1984] offers a way to optimize data viewing for vegetation studies.

The different bands in a multispectral image can be visualized as defining an $N$-dimensional space, where $N$ is the number of bands. Each pixel, positioned according to its data file value in each band, lies within the $N$-dimensional space. This pixel distribution is determined by the absorption/reflection spectra of the imaged material. For viewing purposes, it is advantageous to rotate the $N$-dimensional space such that one or two of the data structure axes are aligned with the view $X$ and $Y$ axes. In particular, the axes that are largest for the data structure produced by the absorption peaks are of special interest for the application. Research has produced three data structure axes that define the vegetation information content. This option can show these three axes (or layers) as a degree of brightness, greenness, and wetness, as calculated by the tasseled cap coefficients used. Layer 1 (red) outputs the brightness component and indicates areas of low vegetation and high reflectors, layer 2 (green) is the greenness component and indicates vegetation status, and layer 3 (blue) is the wetness component that indicates water and moisture in the scene.
The tasseled cap transformation wetness $T C W$ was used to determine the amount of moisture being held by the vegetation or soil, and was thus termed wetness [FADHIL 2009]. TCW images were derived from ETM images of the study area using the tasseled cap transformation algorithm with ER Mapper according to the following equation [JIN, SADER 2005]:

$$
\begin{aligned}
& T C W=0.1509(B)+0.1973(G)+0.3279(R)+ \\
& +0.3406(N I R)-0.7112(S W I R)-0.4572\left(S_{W} R_{2}\right)
\end{aligned}
$$

where $B, G, R, N I R, S W I R$, and $S W I R_{2}$ are the Landsat ETM +6 bands, excluding the thermal bands and the panchromatic band.

\section{Change detection}

Change detection is the process through which changes in the state of a phenomenon are identified by observing it over repeated time intervals. Given the availability of repetitive coverage and a constant image quality, it is one of the main applications of remote sensing.

The change detection approach adopted in this study was a post-classification comparison followed by a change threshold algorithm. It consisted of using the spectral indices calculated (NDVI, NDWI and $T C W$ ) from the four Landsat ETM+ images and then the data classification to produce an image difference algorithm threshold calculation. The products from this procedure were the two change maps corresponding to the difference in values for the beginning and the end of the summer (June and August). Furthermore, to investigate and validate the changes in specific areas in rainfed agriculture, the 44 samples taken during the field work were used to extract the values of the spectral indices for the different images. The spectral index values for the same locations were compared and tested for significant differences for all pairs of images corresponding to a $\alpha$ of 0.01 . Statistical significance was tested for the same months in different years.

\section{RESULTS}

\section{LAND USE LAND COVER (LULC) MAPS}

Four Land Use Land Cover Maps were processed from the Landsat ETM+ images. Based on groundtruth, the accuracy of the finalized LULC maps derived from the Landsat ETM+ images acquired for different periods of the year was calculated. LULC maps consisted of 6 classes (see Fig. 6) that mainly define this rural landscape in central Mexico: forests $(\mathrm{F})$, irrigated agriculture (IA), pastureland $(\mathrm{P})$, rainfed agriculture (RA), shrubland (SH), and water bodies (W). Due to the SLC-off, $15.95 \%$ of the pixels in the study area were lost for all images corresponding to $173.19 \mathrm{~km}^{2}$ for year 2005 . The use of SAADAT et al.'s [2010] methodology to process the LULC maps resulted in very high accuracy, ranging from $87.88 \%$ to 

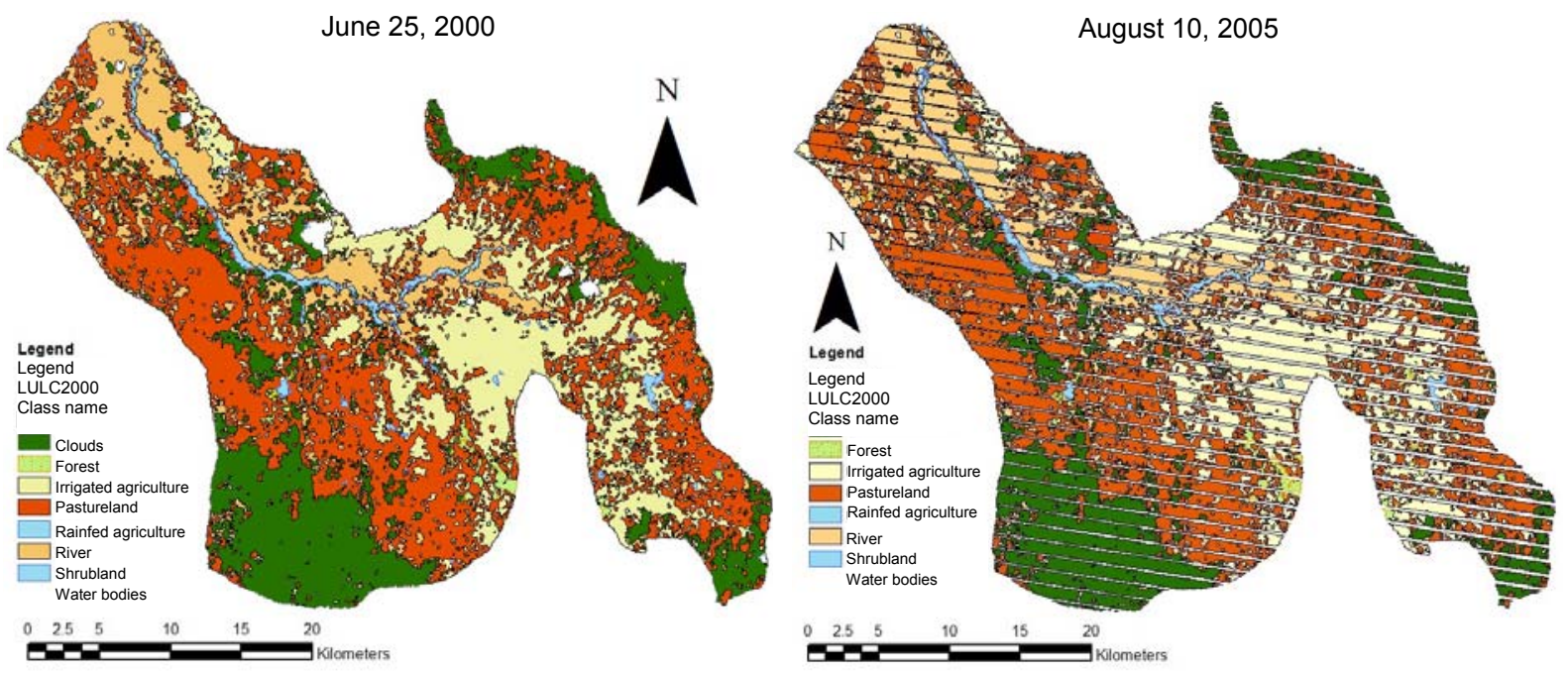

Fig. 6. LULC maps of June 2000 (overall accuracy 90\%) and August 2005 (overall accuracy 97\%); note the effects of SLC-off in the 2005 map were almost $10 \%$ of the image was lost; source: own elaboration

92.42\%. The landscape in central Mexico is very diverse and heterogeneous. Farmers have shaped the land to satisfy their needs and have altered the landscape to overcome abnormally dry conditions by building small dams and water reservoirs. Moreover, farmers have adapted management practices such as irrigating pronominally the most profitable crop in the region, which is alfalfa because of the importance of self-subsistence livestock in the region. Also, fertilizers and pesticides are used to increase yields.

The importance of having very accurate maps is that when detecting change of spectral indices and then evaluating it for each class, the results provide a very precise insight on how the specific class behaved in the year, with an anomalous deficit of precipitation. Such evidence has the potential to be very useful for decision makers to provide solutions for local stakeholders depending on such activities. Note in Table 1 the difference of areas for all classes between those of 2000 and 2005. All areas in 2000 are bigger due to the data gaps of the Landsat imagery SLC-off of 2005. However, the percentage of areas is very similar.

Table 1. Average area for each class for June and August in 2000 and 2005

\begin{tabular}{|l|r|r|r|r|}
\hline \multirow{2}{*}{\multicolumn{1}{|c|}{ Class name }} & \multicolumn{2}{|c|}{ Year 2000 } & \multicolumn{2}{c|}{ Year 2005 } \\
\cline { 2 - 5 } & $\begin{array}{c}\text { area } \\
\mathrm{km}^{2}\end{array}$ & $\begin{array}{c}\text { \% of the } \\
\text { territory }\end{array}$ & $\begin{array}{c}\text { area } \\
\mathrm{km}^{2}\end{array}$ & $\begin{array}{l}\text { \% of the } \\
\text { territory }\end{array}$ \\
\hline Clouds & 11.03 & 1.02 & 0 & - \\
\hline Forest & 211.30 & 19.47 & 176.64 & 19.94 \\
\hline Irrigated agriculture & 23.81 & 2.19 & 19.68 & 2.22 \\
\hline Pastureland & 224.66 & 20.71 & 171.01 & 19.30 \\
\hline Rainfed agriculture & 413.26 & 38.09 & 346.42 & 39.10 \\
\hline River & 15.88 & 1.46 & 9.16 & 1.03 \\
\hline Shrubland & 181.30 & 16.71 & 161.4 & 18.22 \\
\hline Water & 3.76 & 0.35 & 1.763 & 0.20 \\
\hline Total area & 1084.99 & 100.00 & 886.07 & 100.00 \\
\hline
\end{tabular}

Source: own study.

\section{NDVI RESULTS}

In a previous study by SIERRA-SOLER et al. [2015] performed for the same study area as the present paper, a precipitation analysis using the Standardized Precipitation Index of monthly precipitation from January 1980 to December 2012 was performed. In this study the $S P I$ was processed using this monthly data. The 9-month SPI compares the precipitation for that period with the same 9-month period over the historical record, and it is a good indicator of seasonal conditions affecting agriculture. The year 2000 was observed to have normal wetness conditions because it presented consistent positive results within approximately one standard deviation in the 9-month $S P I$ values that increased in April, peaking in the month of June and then diminishing over the subsequent months. The year 2005 persistently showed consistently dry conditions throughout the 6 meteorological stations in the study area. This year presented values ranging from mild drought during the first months of the year, to extreme drought in May, June, and July, according to the SPI results recorded from meteorological stations.

During summer, rainfed crops in central Mexico can be expected to have developed and should be entering the mature stages by the end of summer to be harvested by September. NDVI change detection of the images corresponding to the initial final stages of summer was performed (Fig. 7). The identified negative change in NDVI is significant in the two periods analyzed. For the month of June, most classes showed a significant decrease in $N D V I$ values in most regions (Tab. 2). It was found that for NDVI in June, 85.69\% of the vegetated areas (representing $749.99 \mathrm{~km}^{2}$ ) decreased by $10 \%$ or more. Even though this decrease is relevant, it should be noted that there is an 18 day gap between the two images; however, there were no images available for closer dates to be compared. 


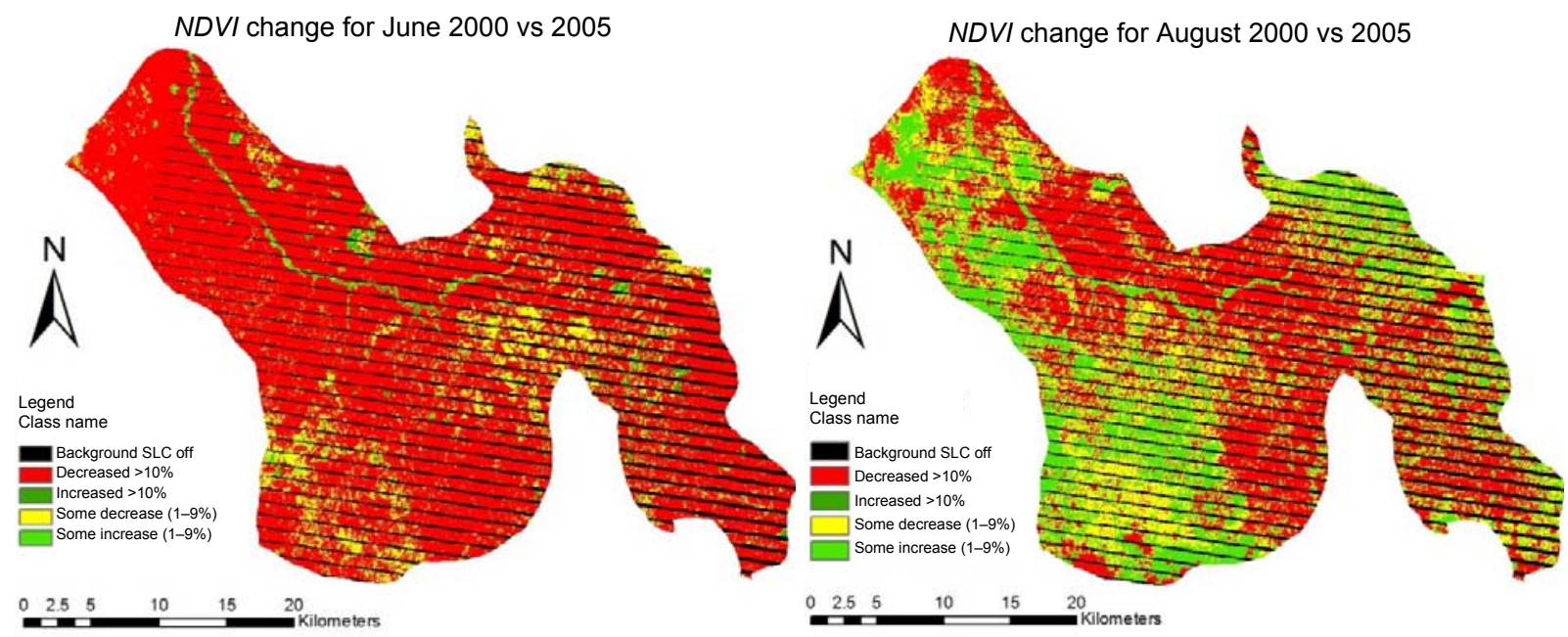

Fig. 7. NDVI change maps of June and August; the comparison was made between the normal year (2000) and the detected dry year (2005); source: own study

Table 2. Area in $\mathrm{km}^{2}$ of each LULC class categorized in the change in NDVI for June 2000 vs. June 2005

\begin{tabular}{|l|c|c|c|c|c|}
\hline \multirow{2}{*}{ Class name } & \multicolumn{5}{|c|}{$\mathrm{Area} \mathrm{km}^{2}$} \\
\cline { 2 - 6 } & $\begin{array}{c}\text { de- } \\
\text { creased } \\
>10 \%\end{array}$ & $\begin{array}{c}\text { some } \\
\text { decrease } \\
(1-9.9 \%)\end{array}$ & $\begin{array}{c}\text { some } \\
\text { increase } \\
(1-9.9 \%)\end{array}$ & $\begin{array}{c}\text { increase } \\
>10 \%\end{array}$ & total \\
\hline Forest & 133.49 & 38.80 & 3.47 & 0.88 & 176.64 \\
\hline $\begin{array}{l}\text { Irrigated } \\
\text { agriculture }\end{array}$ & 17.31 & 1.50 & 0.47 & 0.40 & 19.68 \\
\hline Pastureland & 127.78 & 37.64 & 2.87 & 2.72 & 171.01 \\
\hline $\begin{array}{l}\text { Rainfed } \\
\text { agriculture }\end{array}$ & 318.27 & 21.87 & 3.60 & 2.69 & 346.42 \\
\hline Shrubland & 153.13 & 5.56 & 1.38 & 1.32 & 161.40 \\
\hline Total & 749.99 & 105.38 & 11.78 & 8.00 & 875.15 \\
\hline
\end{tabular}

Source: own study.

Low $N D V I$ values mean there is little difference between the red and NIR signals. This manifestation of a negative change condition is therefore interpreted and associated with a lower photosynthetic activity of an important part of the study area that was analyzed. The August NDVI change map presented a less severe scenario of negative change; however, $74 \%$ of the total territory did experience at least some decrease in photosynthetic activity compared to the normal year. According to the LULC maps, rainfed agriculture represents approximately $58 \%$ of the total region, and for both periods analyzed these were the greatest extensions of land to have significant decreases in $N D V I$ values (see Table 2 and 3 ). It can be noted that $28 \%$ of the area classified as rainfed agriculture had a slight positive change in NDVI. Forests also had a slight increase in $N D V I$, with an increase ranging between $1-9 \%$ of $71.12 \mathrm{~km}^{2}$ of forested area. The area classified as rainfed agriculture (RA) presented significant NDVI change, representing more than $10 \%$ or more in negative change.

During fieldwork, 44 out of the 132 samples corresponding to rainfed agriculture were documented as ground truth data. Such samples were used to extract
Table 3. Area in $\mathrm{km}^{2}$ of each LULC class categorized in the change in NDVI for August 2000 vs. August 2005

\begin{tabular}{|c|c|c|c|c|c|}
\hline \multirow[b]{2}{*}{ Class name } & \multicolumn{5}{|c|}{ Area, $\mathrm{km}^{2}$} \\
\hline & $\begin{array}{c}\text { de- } \\
\text { creased } \\
>10 \%\end{array}$ & $\begin{array}{c}\text { some } \\
\text { decrease } \\
(1-9.9 \%)\end{array}$ & $\begin{array}{c}\text { some } \\
\text { increase } \\
(1-9.9 \%)\end{array}$ & $\begin{array}{c}\text { increase } \\
>10 \%\end{array}$ & total \\
\hline Forest & 37.85 & 66.16 & 71.12 & 0.00 & 175.13 \\
\hline $\begin{array}{l}\text { Irrigated } \\
\text { agriculture }\end{array}$ & 8.56 & 4.91 & 5.98 & 0.00 & 19.45 \\
\hline Pastureland & 117.96 & 43.10 & 0.00 & 19.51 & 180.57 \\
\hline $\begin{array}{l}\text { Rainfed } \\
\text { agriculture }\end{array}$ & 146.65 & 98.70 & 97.21 & 0.00 & 342.57 \\
\hline Shrubland & 86.39 & 41.46 & 30.82 & 0.00 & 158.66 \\
\hline Total & 397.41 & 254.33 & 205.13 & 19.51 & 876.38 \\
\hline
\end{tabular}

Source: own study.

and compare $N D V I$ values for the particular sampled points representing rainfed agricultural lands (Fig. 8). The negative change in the mean values of $N D V I$ for both dates is significant. During the month of June, there was no overlap of $N D V I$ values, representing an evident decrease in vegetation health and a negative mean value of $19.34 \%$ for the sampled points. By $\mathrm{Au}-$ gust, even though there was an overlap of some of the samples taken, the mean value of all points was reduced by $16 \%$. This indicates that the overall health of vegetation for the sampled locations just before the harvest was affected.

\section{NDWI AND SOIL/VEGETATION MOISTURE}

The normalized difference water index $N D W I$ is a measure of liquid water molecules in vegetation canopies that interact with the incoming solar radiation. The NDWI algorithm was processed with the purpose of analyzing the trends in vegetation moisture in the study area in the months of June and August 2000 and 2005; this was done during the summer period since rainfed crops in central Mexico have developed and entered the mature stages by the end of summer and are then harvested by September. 
a)

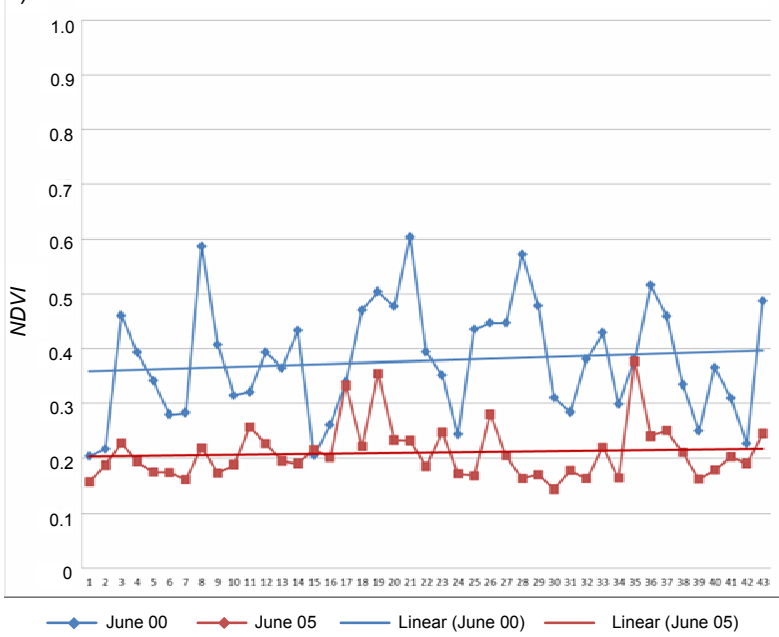

b)

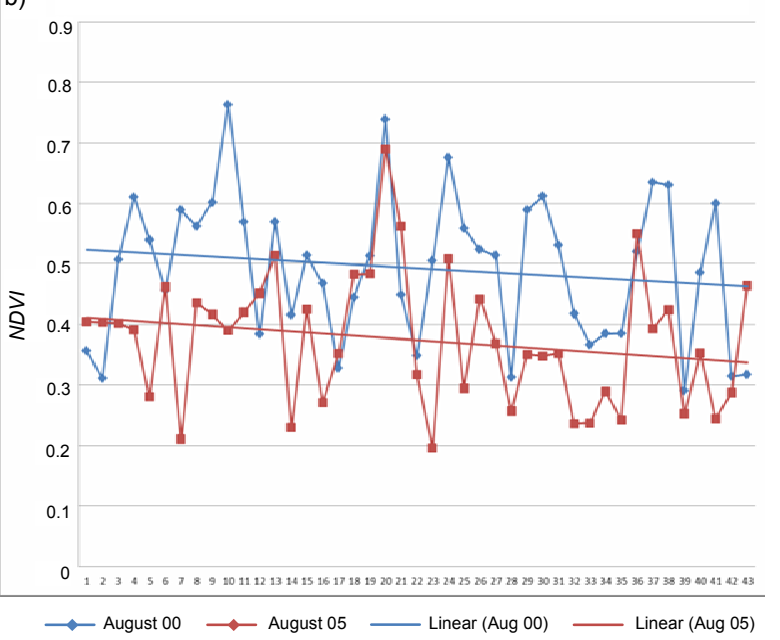

Fig. 8. The 44 samples in rainfed agriculture NDVI values comparison for the initial and final stages of summer; a) June 2000 vs. June 2005; b) August 2000 vs. August 2005 source: own study

Using the LULC classification, the NDWI statistics were extracted for each of the LULC classes. In this way, it was possible to verify the moisture trends of each class in different stages of the growing season (Fig. 9). Each class had consistent patterns of mean NDWI throughout the 18 scenes, with values that slowly increased before the summer and continued to increase until they peaked in the month of August; they then decreased by November when the rainy season ended. All classes peaked in $N D W I$ values during the summer months with the highest values during August. Rainfed agriculture and pasturelands consistently had the lowest values of $N D W I$, but followed the same trends as other classes.

The values for all classes in the year 2005 showed lower than normal values compared to the year 2000. The year 2011 was peculiar, with low values and a decrease for June, and a peak in August. The year 2000 and 2005 were further investigated to compare the behaviors.

Change maps of NDWI were created (Fig. 10). Similar to the NDVI, the identified negative change in NDWI was substantial in the two periods analyzed, and especially for June 2005. For the month of June, most classes showed a significant decrease in NDVI values in most regions (Tab. 4). It was found that for NDWI in June, $81.9 \%$ of the vegetated areas (representing $725.08 \mathrm{~km}^{2}$ ) decreased by $10 \%$ or more. This manifestation of negative change condition is interpreted and associated with lower moisture in the

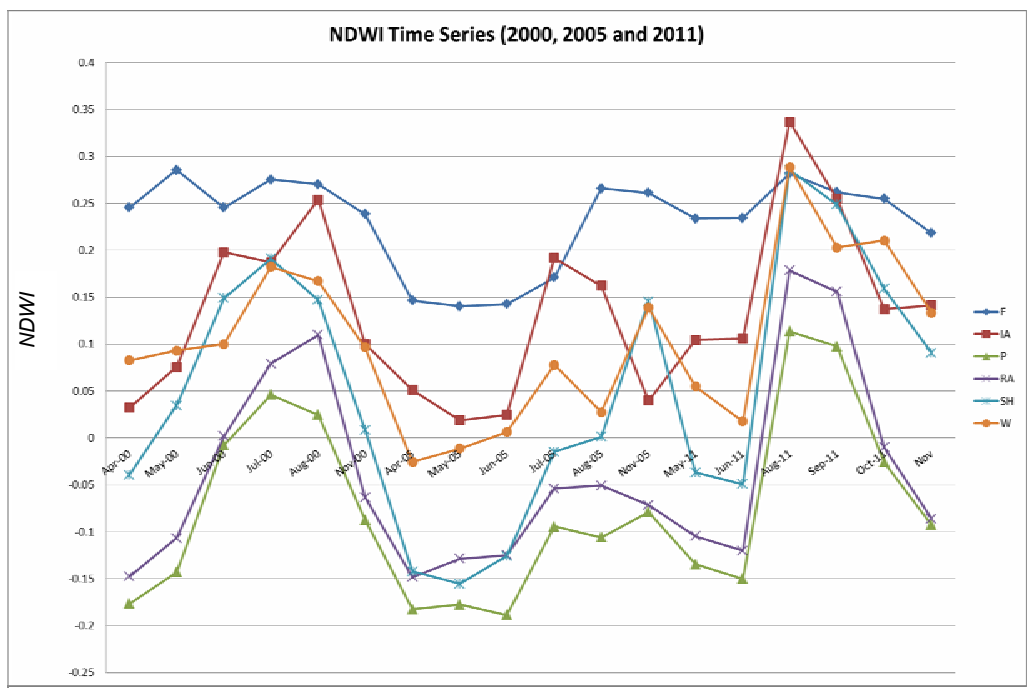

Fig. 9. NDWI trend of time series 2000, 2005 and 2011 for all classes in the 18 mages for used by SIERRA-SOLER et al. [2015]; $\mathrm{F}=$ forest, IA = irrigated agriculture, $\mathrm{P}=$ pastureland, $\mathrm{Sh}=$ shrubland, $\mathrm{RA}=$ rainfed agriculture, $\mathrm{W}=$ water bodies; source: own study

vegetation of significant parts of the study area analyzed.

The case of August change was different. In this month, $20 \%$ of the study area had a significant decrease in NDWI values, while $64 \%$ had some decrease. For the area classified as rainfed agriculture, $84 \%$ had at least some decrease in NDWI; however, $20 \%$ of this area had a $10 \%$ or more decrease.

The NDWI did not show severe negative change for the month of August for most classes. The decrease (1-9\%) could be dismissed; however, it is important to note that rainfed agriculture and pasturelands continuously showed the greatest negative response for the study period. 

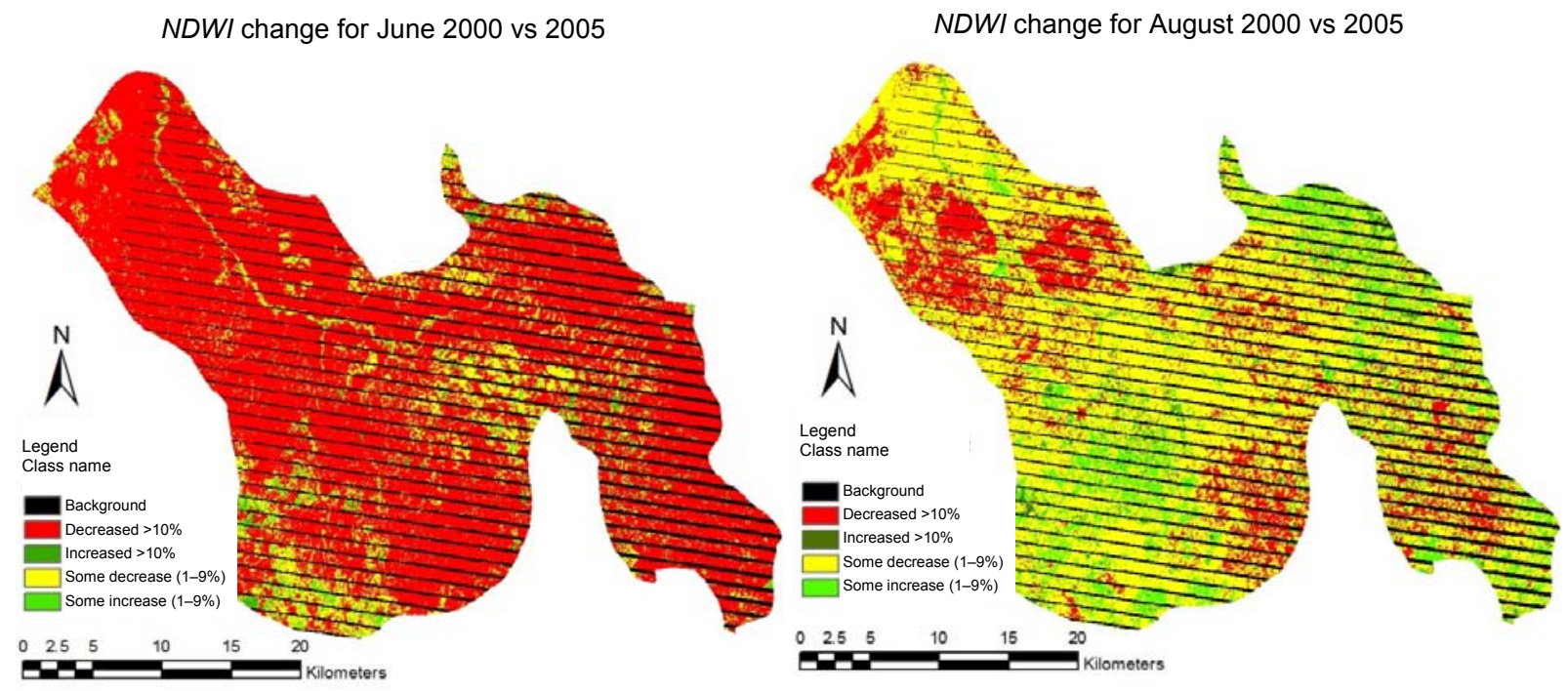

Fig. 10. NDWI change of June and August. The comparison was made between the normal year (2000) and the detected dry year (2005); source: own study

Table 4. Area in $\mathrm{km}^{2}$ of each LULC class categorized in the change in NDWI for June 2000 vs. June 2005

\begin{tabular}{|l|c|c|c|c|r|}
\hline \multirow{2}{*}{ Class name } & \multicolumn{5}{|c|}{$\mathrm{Area}^{\mathrm{k} \mathrm{km}^{2}}$} \\
\cline { 2 - 6 } & $\begin{array}{c}\text { de- } \\
\text { creased } \\
>10 \%\end{array}$ & $\begin{array}{c}\text { some } \\
\text { decrease } \\
(1-9.9 \%)\end{array}$ & $\begin{array}{c}\text { some } \\
\text { increase } \\
(1-9.9 \%)\end{array}$ & $\begin{array}{c}\text { increase } \\
>10 \%\end{array}$ & total \\
\hline Forest & 120.08 & 41.78 & 12.93 & 1.36 & 176.14 \\
\hline $\begin{array}{l}\text { Irrigated } \\
\text { agriculture }\end{array}$ & 17.37 & 1.29 & 0.75 & 0.24 & 19.65 \\
\hline Pastureland & 116.49 & 56.88 & 6.01 & 2.13 & 181.52 \\
\hline $\begin{array}{l}\text { Rainfed } \\
\text { agriculture }\end{array}$ & 319.38 & 19.76 & 4.86 & 2.60 & 346.60 \\
\hline Shrubland & 151.75 & 7.80 & 1.35 & 0.56 & 161.46 \\
\hline Total & 725.08 & 127.50 & 25.91 & 6.89 & 885.38 \\
\hline
\end{tabular}

Source: own study.
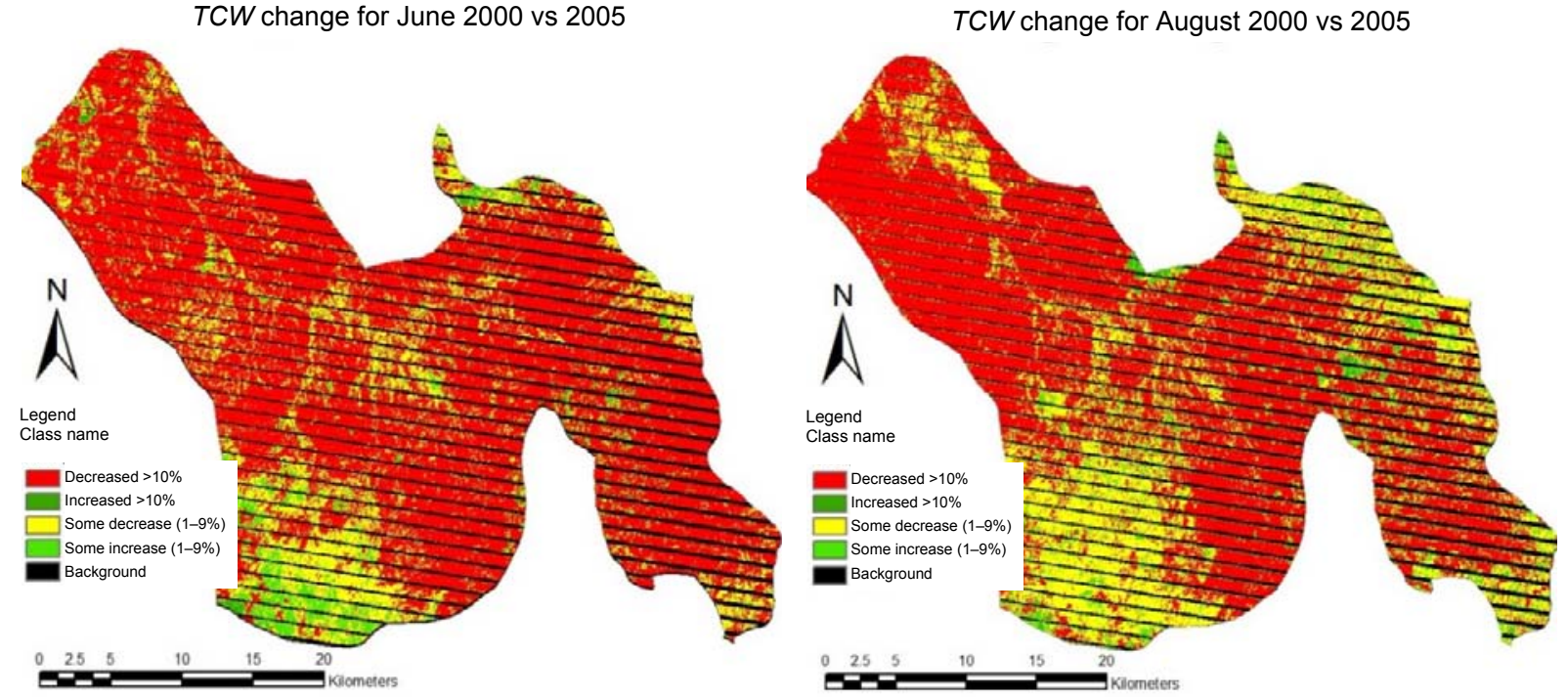

Fig. 11. TCW change of June and August; the comparison was made between the normal year (2000) and the detected dry year (2005); source: own study 
Table 5. Area in $\mathrm{km}^{2}$ of each LULC class categorized in the change in $T C W$ for June 2000 vs. June 2005

\begin{tabular}{|l|c|c|c|c|c|}
\hline \multirow{2}{*}{ Class name } & \multicolumn{5}{|c|}{ Area, $\mathrm{km}^{2}$} \\
\cline { 2 - 6 } & $\begin{array}{c}\text { de- } \\
\text { creased } \\
>10 \%\end{array}$ & $\begin{array}{c}\text { some } \\
\text { decrease } \\
(1-9.9 \%)\end{array}$ & $\begin{array}{c}\text { some } \\
\text { increase } \\
(1-9.9 \%)\end{array}$ & $\begin{array}{c}\text { increase } \\
>10 \%\end{array}$ & total \\
\hline Forest & 68.09 & 71.01 & 0.01 & 35.51 & 174.61 \\
\hline $\begin{array}{l}\text { Irrigated } \\
\text { agriculture }\end{array}$ & 15.97 & 3.42 & 0.00 & 3.40 & 22.80 \\
\hline Pastureland & 157.08 & 19.49 & 0.01 & 3.23 & 179.81 \\
\hline $\begin{array}{l}\text { Rainfed } \\
\text { agriculture }\end{array}$ & 288.81 & 48.44 & 0.02 & 3.33 & 340.60 \\
\hline Shrubland & 120.59 & 26.37 & 0.00 & 12.01 & 158.97 \\
\hline Total & 650.53 & 168.74 & 0.04 & 57.48 & 876.80 \\
\hline
\end{tabular}

Source: own study.

Table 6. Area in $\mathrm{km}^{2}$ of each LULC class categorized in the change in $T C W$ for June 2000 vs. June 2005

\begin{tabular}{|l|c|c|c|c|c|}
\hline \multirow{2}{*}{ Class name } & \multicolumn{5}{|c|}{ Area, $\mathrm{km}^{2}$} \\
\cline { 2 - 6 } & $\begin{array}{c}\text { de- } \\
\text { creased } \\
>10 \%\end{array}$ & $\begin{array}{c}\text { some } \\
\text { decrease } \\
(1-9.9 \%)\end{array}$ & $\begin{array}{c}\text { some } \\
\text { increase } \\
(1-9.9 \%)\end{array}$ & $\begin{array}{c}\text { increase } \\
>10 \%\end{array}$ & total \\
\hline Forest & 68.09 & 75.01 & 25.51 & 5.67 & 174.27 \\
\hline $\begin{array}{l}\text { Irrigated } \\
\text { agriculture }\end{array}$ & 13.97 & 2.42 & 2.40 & 0.95 & 19.75 \\
\hline Pastureland & 127.08 & 19.49 & 3.23 & 29.35 & 179.15 \\
\hline $\begin{array}{l}\text { Rainfed } \\
\text { agriculture }\end{array}$ & 248.81 & 38.44 & 31.69 & 23.47 & 342.41 \\
\hline Shrubland & 110.59 & 24.37 & 19.01 & 4.83 & 158.80 \\
\hline Total & 568.53 & 159.74 & 81.84 & 64.26 & 874.38 \\
\hline
\end{tabular}

Source: own study.

\section{CONCLUSION}

In many semiarid developing regions such as Central Mexico, droughts have the potential to cause crop failure and threaten food security for poor farmers. Rainfed agriculture is practiced widely in these regions, and consequently, poor smallholder producers are exposed to losing their self-sufficiency production. The innovative methodology proposed in this study had the objective of investigating rainfed agriculture response to dry conditions using remotely sensed data. Four Land Use Land Cover (LULC) maps were processed from single imagery using a new methodology, obtaining overall accuracies ranging from the lowest at $87.88 \%$ to the highest at $92.42 \%$. The importance of developing high accuracy LULC maps is based on the fact that when detecting change of spectral indices and then evaluating it for each class, the results provide detailed insight on how specific classes develop in years with dry conditions. The period of study selected corresponded to the months of June and August (initial and final stages of summer) with the objective of understanding vegetation response to dry conditions at a crucial state of development. This period is where rainfed crops in Central Mexico are expected to have developed and entered mature stages by the end of the summer in order to be harvested by September. Three spectral indices (NDVI, NDWI, and $T C W$ ) were processed and analyzed to detect change of a normal and a dry year (2000 and 2005, respectively).

All the spectral indices that were processed indicated a clear decrease in photosynthetic activity $N D V I$ and soil/vegetation moisture (NDWI and $T C W$ ) for the year 2005 compared to 2000 , particularly in the month of June. However, the negative change for the final stages of summer (month of August) should not be underestimated. Persistently, rainfed agriculture and pastureland were the classes that presented the greatest percentages of negative change in all the obtained indices.

The changes perceived in the values of $N D V I$, $N D W I$, and $T C W$ supported the conclusion that vegetation condition was negatively affected by the low rainfall observed in the year 2005. In June 2005 compared to June 2000 , the results showed that $85.7 \%$ of the total study area had a negative change in vegetation condition $N D V I$ and also $81.8 \%$ vegetation/soil moisture NDWI. In both cases, the decrease was of $10 \%$ or more, providing evidence of drought presence. For August 2005 compared to August 2000, $74.3 \%$ of the total study area presented negative change (at least $-5 \%$ ) of vegetation condition NDVI and $83.4 \%$ of vegetation/soil moisture $N D W I$. There is an 18 day gap between the two dates compared; however, there were no images available for closer dates to be compared.

Droughts are difficult to define because of their intricate nature, the variables that influence the phenomenon, and the way they are perceived by the systems in the region of interest. The results presented in this paper could be compared to other semi arid areas; however, drought perception is different for every region because of the different water demand, ecosystems, and infrastructure. In summary NDVI, NDWI, and $T C W$ post classification comparisons and image differencing techniques have proven to be useful methods for tracing environmental changes in the study area, and a similar approach could be explored in other regions.

The proposed methodology has several strengths and weaknesses. High accuracy maps enabled an understanding of how different classes of vegetation changed in condition and soil/vegetation moisture for specific key months of development. This detailed information has the potential to be used as background information for prevention and relief action. Vegetation and soil/vegetation moisture spectral indices used in this study have been very well documented in the literature and are pertinent to detect drought effects on vegetative cover.

The first disadvantage is the above-mentioned 18-day gap between the images analyzed. Furthermore, to quantify the severity of the drought studied in this paper, it should be compared with other periods where dry conditions were present. Landsat 8 was launched in February 11, 2013 and it will provide new imagery of the earth at medium resolution, which could have great potential to be used for drought mon- 
itoring in the future. Future research in the area should focus on comparing other dry events with the results obtained in this study, where significant environmental negative change was found related to dry conditions.

Unlike other natural hazards, the impacts of drought are not reflected on infrastructure and spread over large geographical areas, which results in difficulty in the quantification of impact and for the provision of relief [MishrA, SingH 2010]. The present study found a negative response of vegetation and soil/vegetation moisture for the year 2005; however, further efforts must be made to understand longer time series of imagery to compare the response of this drought to others.

The results have the potential to be used as background information for decision makers such as the Water Council of the State of Hidalgo (CEAAH in Spanish) or the Water National Commission (CONAGUA in Spanish) to identify areas that are more prone to be vulnerable to droughts because of the meteorological and environmental context in which they are situated.

\section{Acknowledgements}

The authors gratefully acknowledge Dr. Margaret Kalacska and Dr. Pablo Arroyo at McGill University for their support in the data analysis process. Data analysis was carried out at the High Performance Computer Laboratory in the Geographic Information Centre in the Department of Geography at McGill University. We also thank: Dr. Sergio CortinaVillar for his insights in Land Use and Management in the rural landscape of Mexico, and Mr. Juan Montes for his help as an experienced guide during the development of the field work carried out in Jan-March 2013. This research was supported by the National Council of Science and Technology of Mexico (CONACYT) and the State Commission of Water and Sewerage of the State of Hidalgo (CEAAH in Spanish). Funding was also provided by an NSERC Discovery Grant and a CFI grant held by Jan Adamowski, as well as a McGill start-up grant held by Dr. Zhiming Qi.

\section{REFERENCES}

AdAmowski J., AdAmowski K., Bougadis J. 2010. Influence of trend on short duration design storms. Water Resources Management. Vol. 24. Iss. 3 p. 401-413.

Adamowski J., Chan H., Prasher S., Sharda V.N. 2012a. Comparison of multivariate adaptive regression splines with coupled wavelet transform artificial neural networks for runoff forecasting in Himalayan microwatersheds with limited data. Journal of Hydroinformatics. Vol. 14. Iss. 3 p. 731-744.

ADAMOWSKI J., PROKOPH A. 2013. Assessing the impacts of the urban heat island effect on streamflow patterns in Ottawa, Canada. Journal of Hydrology. Vol. 496 p. 225-237.

Adamowski K., Prokoph A., AdAmowski J. 2009. Development of a new method of wavelet aided trend detection and estimation. Hydrological Processes. Vol. 23 p. 2686-2696.

AdAMOWSKi K., Prokoph A., ADAmowsKi J. 2012b. Influence of the 11 year solar cycle on annual streamflow maxima in Canada. Journal of Hydrology. Vol. 442-443 p. $55-62$.

APPENDINI K., LiVERMAN D. 1994. Agricultural policy, climate change and food security in Mexico. Food Policy. Vol. 19. Iss. 2 p. 149-164.

Araghi A., Adamowski J., Nalley D., Malard J. 2015. Using wavelet transforms to estimate surface temperature trends and dominant periodicities in Iran based on gridded reanalysis data. Journal of Atmospheric Research. Vol. 11 p. 52-72.

Belayneh A., Adamowski J., Khalil B., OzGa-Zielinski B. 2014. Long-term SPI drought forecasting in the Awash River Basin in Ethiopia using wavelet-support vector regression models. Journal of Hydrology. Vol. 508 p. 418-429.

Bot A., BENITES J. 2005. The importance of soil organic matter: Key to drought-resistant soil and sustained food production. FAO. Web. 16 Oct 2013.

BUTLER C., ADAMOWSKI J. 2015. Empowering marginalized communities in water resources management: Addressing inequitable practices in Participatory Model Building. Journal of Environmental Management. Vol. 153 p. $153-162$.

CAMPiSi S., ADAmowski J., ORON G. 2012. Forecasting urban water demand via wavelet- denoising and neural network models. Case study: city of Syracuse, Italy. Water Resources Management. Vol. 26 p. 3539-3558.

Cohen Y., Shoshany M. 2002. A national knowledge-based crop recognition in Mediterranean environment. International. Journal of Applied Earth Observation and Geoinformation. Vol. 4. Iss. 1 p. 75-87.

CONANP 2003. Programa de Manejo Reserva de La Biosfera Barranca de Metztitlán. Mexico DF.

CRist E., Cicone R. 1984. A physically-based transformation of Thematic Mapper data - The TM Tasseled Cap. Geoscience and Remote Sensing, IEEE Transactions. Vol GE-22. Iss. 3 p. 256-263.

Daneshmand F., Karimi A., Nikoo M., Bazargan-Lari M., AdAmowsKi J. 2014. Mitigating socio-economicenvironmental impacts during drought periods by optimizing the conjunctive management of water resources. Water Resources Management. Vol. 28. Iss. 6 p. $1517-$ 1529.

DE ASIS A., OMASA K. 2007. Estimation of vegetation parameter for modeling soil erosion using linear Spectral Mixture Analysis of Landsat ETM data. ISPRS Journal of Photogrammetry and Remote Sensing. Vol. 62. Iss. 4 p. 309-324.

Diouf A., LAMBIN E. 2001. Monitoring land-cover changes in semi-arid regions: remote sensing data and field observations in the Ferlo, Senegal. Journal of Arid Environments. Vol. 48. Iss. 2 p. 129-148.

EAKIN H. 2000. Smallholder maize production and climatic risk: A case study from Mexico. Climatic Change. Vol. 45. Iss. 1 p. 19-36.

FADHIL A. 2011. Drought mapping using Geoinformation technology for some sites in the Iraqi Kurdistan region. International Journal of Digital Earth. Vol. 4. Iss. 3 p. 239-257.

Focardi S., Loiselle S.A., MAZzuoli S., Bracchini L., DAtTILO A.M., Rossi C. 2008. Satellite-based indices in the analysis of land cover for municipalities in the province of Siena, Italy. Journal of Environmental Management. Vol. 86. Iss. 2 p. 383-389.

GAO B. 1996. NDWI A normalized difference water index for remote sensing of vegetation liquid water from 
space. Remote Sensing of Environment. Vol. 58. Iss. 3 p. $257-266$.

Goward S., Compton J., Dye D. 1985. North American vegetation patterns observed with the NOAA-7 advanced very high resolution radiometer. Vegetatio. Vol. 64. Iss. 1 p. $3-14$.

Gu Y., Brown J. F., Verdin J. P., Wardlow B. 2007. A five-year analysis of MODIS NDVI and NDWI for grassland drought assessment over the central Great Plains of the United States. Geophysical Research Letters. Vol. 34. Iss. 6.

Gu Y., Hunt E., Wardlow B., Basara J.B., Brown J.F., VERDIN J.P. 2008. Evaluation of MODIS NDVI and NDWI for vegetation drought monitoring using Oklahoma Mesonet soil moisture data. Geophysical Research Letters. Vol. 35. Iss. 22.

Haidary A., Amiri B.J., AdAmOwSki J., Fohrer N., NAKANE K. 2013. Assessing the impacts of four land use types on the water quality of wetlands in Japan. Water Resources Management. Vol. 27. Iss. 7 p. 2217-2229.

Halbe J., Pahl-Wostl C., Sendzimir J., Adamowski J. 2013. Towards adaptive and integrated management paradigms to meet the challenges of water governance. Water Science and Technology: Water Supply. Vol. 67. Iss. 11 p. 2651-2660.

HewitT K. 1997. Regions of risk: A geographical introduction to disasters. London. Longman. ISBN 0582210054 pp. 389.

InAm A., AdAmowski J., HalBe J., Prasher S. 2015. Using causal loop diagrams for the initialization of stakeholder engagement in soil salinity management in agricultural watersheds in developing countries: A case study in the Rechna Doab watershed, Pakistan. Journal of Environmental Management. Vol. 152 p. 251-267.

JiN S., SADER S. 2005. Comparison of time series tasseled cap wetness and the normalized difference moisture index in detecting forest disturbances. Remote Sensing of Environment. Vol. 94. Iss. 3 p. 364-372.

JOHAN R. 2003. Resilience building and water demand management for drought mitigation. Physics and Chemistry of the Earth. Parts A/B/C. Vol. 28. Iss. 20 p. 869877.

Joshi P.K., Roy P.S., Singh S., Agrawal S., YadAV D. 2006. Vegetation cover mapping in India using multitemporal IRS Wide Field Sensor (WiFS) data. Remote Sensing of Environment. Vol. 103 p. 190-202.

KoGAN F. 1990. Remote sensing of weather impacts on vegetation in non-homogeneous areas. International Journal of Remote Sensing. Vol. 11. Iss. 8 p. 1405 1419.

KogAn F. 1995a. Application of vegetation index and brightness temperature for drought detection. Advances in Space Research. Vol. 15. Iss. 11 p. 91-100.

Kogan F. 1995b. Droughts of the late 1980s in the United States as derived from NOAA Polar-Orbiting Satellite data. Bulletin of the American Meteorological Society. Vol. 76. Iss. 5 p. 655-668.

Kolinjivadi V., ADAmOwski J., Kosoy N. 2014a. Juggling multiple dimensions in a complex socioecosystem: The issue of targeting in payments for ecosystem services. GeoForum. Vol. 58 p. 1-13.

KolinjiVAdi V., ADAmowsKi J., Kosoy N. 2014b. Recasting payments for ecosystem services (PES) in water resource management: A novel institutional approach. Ecosystem Services. Vol. 10 p. 144-154.

Labrecque S., Fournier R.A., Luther J. E., Piercey D. 2006. A comparison of four methods to map biomass from Landsat-TM and inventory data in western Newfoundland. Forest Ecology and Management. Vol. 226. Iss. 1 p. 129-144.

LenNeY M.P., Woodcock C.E., Collins J.B., Hamdi H. 1996. The status of agricultural lands in Egypt: the use of multitemporal NDVI features derived from Landsat TM. Remote Sensing of Environment. Vol. 56. Iss. 1 p. $8-20$.

LiVERMAN D. 1990. Drought impacts in Mexico: Climate, agriculture, technology, and land tenure in Sonora and Puebla. Annals of the Association of American Geographers. Vol. 80. Iss. 1 p. 49-72.

Mahmoud S., Adamowski J., Alazba A., El-Gindy A. 2015. Rainwater harvesting for the management of agricultural droughts in arid and semi-arid regions. Paddy and Water Environment. In press.

Maselli F., Conese C., Petkov L., Resti R. 1992. Inclusion of prior probabilities derived from a nonparametric process into the maximum-likelihood classifier. Photogrammetric Engineering and Remote Sensing. Vol. 58. No. 2 p. 201-207.

Medema W., Light S., AdAmowski J. 2014. Integrating adaptive learning into water resources management. Journal of Environmental Engineering and Management. Vol. 13. Iss. 7 p. 1801-1816.

Medema W., Wals A., AdAmowski J. 2014. Virtual learning platforms for sustainable land and water governance: An innovative mechanism for facilitating multiloop social learning. Wageningen University Journal of Life Sciences. Vol. 69 p. 23-38.

Mishra A., Singh V. 2010. A review of drought concepts. Journal of Hydrology. Vol. 391. Iss. 1 p. 202-216.

Nalley D., Adamowski J., Khalil B. 2012. Using discrete wavelet transforms to analyze trends in streamflow and precipitation in Quebec and Ontario (1954-2008). Journal of Hydrology. Vol. 475 p. 204-228.

Nalley D., AdAmOWSKi J., Khalil B., OZGa-ZielinsKi B. 2013. Trend detection in surface air temperature in Ontario and Quebec, Canada during 1967-2006 using the discrete wavelet transform. Journal of Atmospheric Research. Vol. 132-133 p. 375-398.

NAMdAR M., AdAMOWSKi J., SAADAT H., Sharifi F., KHIRI A. 2014. A new approach to developing LULC maps for semi-arid regions using independent component analysis and expert classification. International Journal of Remote Sensing. Vol. 35. Iss. 24 p. 8057-8073.

Niazi A., Prasher S., Adamowski J. 2014. A system dynamics model to conserve arid region water resources through aquifer storage and recovery in conjunction with a dam. Journal of Water. Vol. 6. Iss. 12 p. 23002321.

OBASI G.O.P. 1994. WMO's role in the international decade for natural disaster reduction. Bulletin of the American Meteorological Society. Vol. 75. Iss. 9 p. 1655-1661.

Oetter D.R., Cohen W.B., Berterretche M., MaierSPERGER T.K., KENNEDY R.E. 2001. Land cover mapping in an agricultural setting using multiseasonal thematic mapper data. Remote Sensing of Environment. Vol. 76. Iss. 2 p. 139-155.

PANU U., Sharma T. 2002. Challenges in drought research: Some perspectives and future directions. Hydrological Sciences Journal. Vol. 47 p. S19-S30.

Peters A.J., WAlter-Shea E.A., Ji L., VinA A., Hayes M., SvoBODA M.D. 2002. Drought monitoring with NDVIbased standardized vegetation index. Photogrammetric Engineering and Remote Sensing. Vol. 68. No. 1 p. 7175 . 
Pingale S., Khare D., Jat M., Adamowski J. 2014. Spatial and temporal trends of mean and extreme rainfall and temperature for the 33 urban centres of the arid and semi-arid state of Rajasthan, India. Journal of Atmospheric Research. Vol. 138 p. 73-90.

QUARMBY J., ForSTER C. 1995. An examination of the structure of UASB granules. Water Research. Vol. 29. Iss. 11 p. 2449-2454.

RAHIMZADEH BAJgiRAN P., DARVishSEFAT A.A., Khalili A., MAKHDOUM M.F. 2008. Using AVHRR-based vegetation indices for drought monitoring in the Northwest of Iran. Journal of Arid Environments. Vol. 72. Iss. 6 p. 1086-1096.

RAHIMZAdEh-BAJgiran P., OMASA K., ShimizU Y. 2012. Comparative evaluation of the Vegetation Dryness Index (VDI), the Temperature Vegetation Dryness Index (TVDI) and the Improved TVDI (iTVDI) for water stress detection in semi-arid regions of Iran. ISPRS Journal of Photogrammetry and Remote Sensing. Vol. 68 p. 1-12.

RASMUSSEN M. 1992. Assessment of millet yields and production in Northern Burkina Faso using integrated NDVI from the AVHRR. International Journal of Remote Sensing. Vol. 13. Iss. 18 p. 3431-3442.

REDMOND K. 2002. The depiction of drought: A commentary. Bulletin of the American Meteorological Society. Vol. 83. Iss. 8 p. $1143-1147$.

RHEE J., Im J., CARBone G. 2010. Monitoring agricultural drought for arid and humid regions using multi-sensor remote sensing data. Remote Sensing of Environment. Vol. 114. Iss. 12 p. 2875-2887.

Ruefenacht B., VANDERZANDEN D., Morrison M. 2002. New technique for segmenting images. Salt Lake City. USDA Forest Service Remote Sensing Applications Center.

SaAdat H., Adamowski J., Bonnell R., Sharifi F., NAMDAR M., Ale-Ebrahim S. 2011. Land use and land cover classification over a large area in Iran based on single date analysis of satellite imagery. Journal of Photogrammetry and Remote Sensing. Vol. 66 p. 608-619.

SAADAT H., AdAMOWSKi J., TAYefi V., NAMdAR M., ShariFi F., Ale-Ebrahim S. 2014. A new approach for regional scale interrill and rill erosion intensity mapping using brightness index assessments from medium resolution satellite images. Catena. Vol. 113 p. 306-313.
Sierra-Soler A., Adamowski J., Malard J., SaAdat H., QI Z. 2015. Assessing agricultural drought at a regional scale using LULC classification, SPI, and vegetation indices: Case study in a rainfed agro-ecosystem in Central Mexico. Journal of Geomatics, Natural Hazards and Risk. In press.

SivanPillai R., SRinivasan R., Smith C. T., Messina M.G., WU X.B. 2007. Estimating regional forest cover in east Texas using Advanced Very High Resolution Radiometer (AVHRR) data. International Journal of Applied Earth Observation and Geoinformation. Vol. 9. Iss. 1 p. 41-49.

Straith D., Adamowski J., Reilly K. 2014. Exploring the attributes, strategies and contextual knowledge of champions of change in the Canadian water sector. Canadian Water Resources Journal. Vol. 393 p. 255-269.

TIWARI M., ADAMOWSKI J. 2013. Urban water demand forecasting and uncertainty assessment using ensemble wavelet-bootstrap-neural network models. Water Resources Research. Vol. 49. Iss. 10 p. 6486-6507.

Unganai L., Kogan F. 1998. Drought monitoring and corn yield estimation in Southern Africa from AVHRR data. Remote Sensing of Environment. Vol. 63. Iss. 3 p. 219 232.

Vanderpost C., Ringrose S., Matheson W., Arntzen J. 2011. Satellite based long-term assessment of rangeland condition in semi-arid areas: An example from Botswana. Journal of Arid Environments. 75. P. 383389.

Wardlow B., EgBert S., Kastens J. 2007. Analysis of time-series MODIS $250 \mathrm{~m}$ vegetation index data for crop classification in the U.S. Central Great Plains. Remote Sensing of Environment. Vol. 108. Iss. 3 p. 290 310 .

Wilhelmi O., Wilhite D. 2002. Assessing vulnerability to agricultural drought: A Nebraska case study. Natural Hazards. Vol. 25. Iss. 1 p. $37-58$.

Wilhite D., Svoboda M., Hayes M. 2007. Understanding the complex impacts of drought: A key to enhancing drought mitigation and preparedness. Water Resources Management. Vol. 21. Iss. 5 p. 763-774.

YUREKLI K., KURUNC K. 2006. Simulating agricultural drought periods based on daily rainfall and crop water consumption. Journal of Arid Environments. Vol. 67. Iss. 4 p. $629-640$.

\section{Andres SIERRA-SOLER, Jan ADAMOWSKI, Zhiming QI, Hossein SAADAT, Santosh PINGALE}

\section{Dokładne mapy użytkowania i pokrycia terenu (LULC) w śledzeniu suszy rolniczej w zasilanych opadowo agro-ekosystemach środkowego Meksyku}

\section{STRESZCZENIE}

\section{Słowa kluczowe: mapy LULC, susza, teledetekcja, wskaźniki spektralne}

Teledetekcja zapewnia synoptyczny ogląd Ziemi i kontekst przestrzenny do pomiarów efektów susz, co okazało się cennym źródłem ciągłych danych dla monitorowania dynamiki roślinności. Wiele badań koncentrowało się na śledzeniu skutków suszy na rozległych obszarach ze względu na łatwą dostępność obrazów o małej rozdzielczości. Celem przedstawionej pracy była jednak analiza mniejszego obszaru $\left(1085 \mathrm{~km}^{2}\right)$ z użyciem zdjęć Landsat ETM+ (wielospektralna rozdzielczość $30 \mathrm{~m}$, panchromatyczna - $15 \mathrm{~m}$ ) oraz przeprowadzenie dokładnej klasyfikacji użytkowania i pokrycia powierzchni terenu (ang. Land Use Land Cover - LULC) z zamiarem określenia z dużą dokładnością skutków suszy w poszczególnych klasach. Terenem badań była Tortugas-Tepezata, 
zlewnia II rzędu rzeki Moctezuma, zlokalizowana w stanie Hidalgo w środkowym Meksyku. Klasyfikację LULC przeprowadzono z użyciem nowej metody bazującej na dostępnych dodatkowych informacjach i analizie trzech zdjęć satelitarnych wykonanych w różnym czasie. Opracowana na nowo metodyka LULC zapewniła dokładność w granicach od 87,88 do $92,42 \%$. Spektralne wskaźniki dla roślinności i wilgotności gleby oraz roślin wykorzystano do wykrycia anomalii w rozwoju roślinności spowodowanych suszą. Ponadto zmierzono i porównano powierzchnię zbiorników wodnych w celu sprawdzenia zmian w dostępności wody do nawadniania upraw. Proponowana metodyka może służyć jako narzędzie szczegółowej identyfikacji skutków suszy w zasilanych opadowo obszarach rolniczych oraz jako mechanizm zapobiegania i łagodzenia skutków suszy. 